\title{
Forkhead Box Protein M1
}

National Cancer Institute

\section{Source}

National Cancer Institute. Forkhead Box Protein M1. NCI Thesaurus. Code C101582.

Forkhead box protein M1 (763 aa, $~ 84 \mathrm{kDa}$ ) is encoded by the human FOXM1 gene. This protein is involved in the regulation of both mitosis and transcription. 